УДК 378:[780.647.2.071.4:1.02]

DOI 10.25128/2415-3605.21.1.18

\title{
ЗІНОВІЙ СТЕЛЬМАЩУК
}

https://orcid.org/0000-0001-9133-2876

zistel@ukr.net

кандидат педагогічних наук, доцент

Тернопільський національний педагогічний університет імені Володимира Гнатюка

вул. В. Винниченка, 10, м. Тернопіль

\section{ВИКОНАВСЬКА МАЙСТЕРНІСТЬ АКОРДЕОНІСТА В КОНТЕКСТІ ФАХОВОЇ ПІДГОТОВКИ МУЗИКАНТА-ПЕДАГОГА}

Акцентовано увагу на важливості підготовки музиканта-педагога, підвищення якості його навчання шляхом досягнення необхідни компетенцій, однією з яких є інструментально-виконавська майстерність. Проаналізовано базові умови, які впливають на розвиток виконавської майстерності майбутнього педагога, а саме: опанування міцними знаннями з ичиллу культурологічних, музикознавчих $i$ психолого-педагогічних дисциплін, тісно пов'язаними з епохою, сочіумом, способом життя, суспільноісторичними умовами, творчим середовищем тощо, які становлять базу виконавської культури вчителя-інструменталіста. Висвітлено основні чинники розвитку $i$ вдосконалення виконавської майстерності, щзо передбачають технології читання нотного тексту з аркуша та ескізне вивчення інструментальних творів на акордеоні. Охарактеризовано поняття «інтонація», щзо стала предметом дослідження багатьох вчених, музикознавиів, композиторів, виконавців, як один з найбільи дієвих способів створення композитором музичного образу, через який проходить весь механізм відтворення змісту та емочійної глибини музичних творів. Наведено приклади «розиифровування» інтонації за виражальними властивостями в процесі інтерпретації твору, коли виконавець стає співавтором композитора, проникаючи у музичний образ через знання стилів, жанрів, виражальних властивостей ладу і його тяжінь, розв'язання інтервалів, акордів, гармонічних послідовностей, багатства образновиражальних властивостей інтонації в цілому комплексі виконавських засобів.

Ключові слова: виконавська майстерність, акордеоніст, репертуар, інтоначія, інтерпретація.

\section{ЗИНОВИЙ СТЕЛЬМАЩУК}

кандидат педагогических наук, доцент Тернопольский национальный педагогический университет имени Владимира Гнатюка

ул. В. Винниченко, 10, г. Тернополь

\section{ИСПОЛНИТЕЛЬСКОЕ МАСТЕРСТВО АККОРДЕОНИСТА В КОНТЕКСТЕ ПРОФЕССИОНАЛЬНОЙ ПОДГОТОВКИ МУЗЫКАНТА-ПЕДАГОГА}

Акиентировано внимание на важности подготовки музыканта-педагога, повышения качества его обучения путем достижения необходимых компетенций, одной их которых является инструментальноисполнительское мастерство. Сделан анализ базовых условий, которые влияют на развитие исполнительского мастерства будущего педагога, а именно: овладение крепкими знаниями из иикла культурологических, музыковедческих и психолого-педагогических дисииплин, тесно связанных с эпохой, социумом, образом жизни, общественно-историческими условиями, творческой средой и тому подобное, которые составляют базис исполнительской культуры учителя-инструменталиста. Освещены основные факторы развития и усовершенствования исполнительского мастерства, которые предусматривают технологии чтения нотного текста с листа и эскизное изучение инструментальных произведений на аккордеоне. Дана характеристика понятия «интонация», которая стала исследованием многих ученых, музыковедов, исполнителей, как один из самых действенных способов создания композитором музыкального образа, через который проходит весь механизм воспроизведения содержания и эмоциональной глубины музыкальных произведений. Наведены примеры "расшифровки» интонации по выразительным свойствам в процессе интерпретации произведения, когда исполнитель становится соавтором композитора, проникая в музыкальный образ через знания стилей, жанров, выразительных свойств лада и его тяготений, развязывания интервалов, аккордов, гармонических 
последовательностей, богатства образно-выразительных свойств интоначии в иелом комплексе исполнительских средств.

Ключевые слова: исполнительское мастерство, аккордеонист, репертуар, интонация, интерпретачия.

\section{ZINOVII STELMASHCHUK}

Candidate of Pedagogical Science, Associate Professor Volodymyr Hnatiuk Ternopil National Pedagogical University 10 Vynnychenko Str., Ternopil

\section{PERFORMING SKILLS OF ACCORDIONIST IN THE CONTEXT OF PROFESSIONAL TRAINING OF A TEACHER-MUSICIAN}

The article emphases the importance of training a teacher-musician, improving the quality of his education by achieving the necessary competencies, one of which is instrumental performance. The basic conditions that affect the development of performing skills of the future teacher are analyzed in the work, which are mastering strong knowledge from the cycle of cultural, musicological and psychological and pedagogical disciplines, closely related to the certain historical period, society, way of life, socio-historical conditions, creative environment, etc., which form the basis of the performing culture of the teacher and instrumentalist. The main factors of development and improvement of performing skills are highlighted, which include technologies of sheet music reading and study of accordion instrumental works. The concept of "intonation", which has been the subject of research by many scientists, musicologists, composers, performers, is described as one of the most effective ways for a composer to create a musical image through which the whole mechanism of reproducing the content and emotional depth of musical works. The article contains examples of "deciphering" intonation by expressive properties in the process of interpreting the work, when the performer becomes a co-author of the composer, penetrating the musical image through knowledge of styles, genres, expressive properties of the system and its tendencies, intervals, chords, harmonic sequences, expressive properties of intonation in the whole complex of performing.

Keywords: performing skills, accordionist, repertoire, intonation, interpretation.

Нинішній техногенно-інформаційний динамічний розвиток суспільства вимагає створення адекватних умов в системі професійної підготовки вчителя музичного мистецтва. Значної ролі при цьому набуває підвищення якості його навчання шляхом досягнення необхідних компетенцій і компетентностей. Відповідно до сучасних вимог вчитель музичного мистецтва повинен володіти широким спектром знань умінь і навичок. Утім разом 3 іншими навичками професійна діяльність його вимагає повною мірою володіти одним 3 музичних інструментів. Тому важливою складовою фахової компетенції майбутнього педагога-музиканта $\epsilon$ інструментальна підготовка. Про це постійно наголошують науковці та вчителі-практики, які відзначають значущість володіння музичним інструментом. Одним 3 важливих чинників професіоналізму в контексті інструментальної підготовки вчителя-музиканта $\epsilon$ його виконавська майстерність. У роботі мова буде йти про акордеоністів, хоч сказане, до певної міри, може стосуватися виконавців на інших музичних інструментах.

У музичній педагогіці і психології проблемі технологій інструментальної підготовки майбутніх фахівців присвячені дослідження Л. Арчажнікової, М. Булди, Т. Воробкевич, Г. Гінзбурга, О. Гольденвейзера, Л. Горенка, І. Гофмана, М. Давидова, В. Князєва, Г. Нейгауза, Г. Падалки, А. Семешка, Г. Ципіна, Г. Шахова та інших науковців, де зокрема акцентується увага на розвитку їх виконавської майстерності.

Мета статті - здійснити аналіз базових умов, основних чинників, які впливають на розвиток виконавської майстерності акордеоніста.

Виконавська майстерність, як суттєва і взаємодоповнююча частина інструментальної підготовки вчителя-музиканта, складається з певних базових умов і чинників.

Однією з умов є опанування міцними знаннями з циклу культурологічних, музикознавчих та психолого-педагогічних дисциплін, що становлять базу виконавської культури вчителяінструменталіста, а саме: «знання теорії і історії музичних стилів (сучасних в тому числі - поп, рок, джаз, тощо), художніх стилів інших видів мистецтв з метою розвитку образного мислення, творчої уяви, фантазії, асоціативних зв'язків. Він має знати історію музичного інструмента, 
творчість і стильові особливості композиторів, що писали для даного музичного інструмента, історичну, виконавську, педагогічну спадщину видатних педагогів-інструменталістів та особливості їх методик викладання гри на музичних інструментах» [8, с. 76].

Наступна умова зумовлена тим, що в музично-виконавській сфері сучасного покоління молоді відбулися певні об'єктивні зрушення і відмінності, які не можуть бути непоміченими. У цьому контексті варто згадати відомий вислів: «Художник і Час завжди поєднані тисячею уз». Інакше кажучи, виконавець тісно пов'язаний з «духом часу»: епохою, соціумом, способом життя, суспільно-історичними умовами, творчим середовищем, тощо. Під впливом цих факторів змінюється, природно, внутрішній світ людини: психологічна структура, склад мислення, сфера почуттів, а відтак загалом - музично-виконавське мистецтво. Сьогодні вчені спостерігають певні відмінні властивості особистості, які властиві сучасній епосі. Однією 3 таких властивостей у творчості особистості $\epsilon$ раціоналізм. Почуття, відкритість душі, романтична окриленість відходять на другий план. Аналогічні процеси відбуваються не тільки у сфері інструментального виконавства, а й в театральному середовищі (за свідченням фахівців, переживання і жива емоція теж поступово виходить з театру). Це говорить про те, що сучасне покоління стало іншим, більш прагматичним, ніж раніше.

Утім, 3 іншого боку, психологи запевняють, що емоційний фонд людини не зазнає особливих змін. Він лише у процесі суспільно-історичного розвитку людської особистості удосконалюється, стає «інтелектуалізованішим». Внаслідок цього і видозмінюється виконавське мистецтво у формі, змісті, засобах вираження, «творчих імпульсах» тощо. Наведені фактори апріорі необхідно враховувати у процесі підготовки вчителя-музиканта в аспекті його інструментальної виконавської майстерності.

Процес розвитку і вдосконалення виконавської майстерності передбачає і такі домінуючі чинники: читання нот з аркуша; ескізне вивчення творів; розкриття ідеї музичного твору й уміння його інтерпретації.

Зупинимося детальніше на їх характеристиках задля вдосконалення виконавської майстерності гри на акордеоні.

Загальновідомо, що вчитель-музикант за період навчання гри на музичному інструменті повинен освоїти максимальний за обсягом навчально-педагогічний репертуар. До виходу на педагогічну практику він накопичує «золотий» запас різножанрових i різностильових інструментальних п’єс, пісень 3 репертуару для слухання музики і вокально-хорової роботи, щоб бути готовим до «живого» виконання творів на уроках музичного мистецтва і під час позакласних музично-виховних занять. 3 практичного досвіду можемо констатувати, що виконавські вміння і навички, які формуються у студентів в процесі навчання гри на акордеоні, як правило, обмежені в часі. Більшість студентів, особливо з базовою освітою дитячої музичної школи, в практичній інструментальній підготовці не виходять за межі вузького кола «відпрацьованого» 3 викладачем репертуару. Виникає питання: «Як розширити репертуарні рамки?». На допомогу приходять два, достатньо описані науковцями, методистами, педагогами-практиками й апробовані автором цієї статті, види роботи на заняттях в класі акордеона: читання нот 3 аркуша й «ескізне» (ознайомлювальне) вивчення творів. Про технології і важливість цієї роботи вже багато сказано в науковій і навчально-методичній літературі. Однак варто зупинитися на ключових вимогах і основних правилах, рекомендаціях, якими необхідно озброїтись студентові і використовувати викладачеві в практичній діяльності.

Передусім необхідно пам'ятати про психологічний аспект, тобто важливість цих видів роботи. Вміння читати музику з аркуша і розучувати іiі ескізно відкриває широкі можливості для ознайомлення з великою кількістю різноманітної музичної літератури. При цьому власне акордеоніст, крім оригінального репертуару, може користуватися збірниками творів для баяна, фортепіано, вокальних творів, що сприятиме постійній зміні музичних вражень і притоку нової музичної продукції. «Скільки читаємо - стільки знаємо» - ця відома істина може стосуватись $\mathrm{i}$ музиканта-інструменталіста. Ознайомлення із значною кількістю музичного матеріалу створює сприятливі умови не тільки для розвитку виконавської майстерності акордеоніста, а й для загального музичного розвитку, оскільки 3 такого набору творів, який не треба вчити напам'ять, шліфувати, вдосконалювати, складається особливе «психологічне налаштування» на відкриття і пізнання нового в музичному інформаційному потоці. 
Про важливість i користь читання нот 3 першого погляду - a prima vista висловлювалися Ф.-Е. Бах, Ф. Ліст, С. Рахманінов, Х. Шубарт та інші відомі композитори і виконавці. Педагоги-практики пропонують різні методики читання: від кількісного накопичення різноманітного нотного матеріалу за принципом «чим більше - тим краще» $[4$, c. 176] до різних методичних вказівок (Т. Воробкевич, Г. Ципін, Г. Шахов та ін.).

Музикантам з високорозвиненим внутрішнім слухом у процесі читання нотного тексту Б. Теплов, наприклад, рекомендував перетворювати ноти в звукову картину за схемою «бачу чую - граю», тобто «слухати очима» [9, с. 186]. «Якщо тобі пропонують зіграти 3 аркуша невідомий твір, то спочатку пробіжи його очима», - рекомендував Р. Шуман своєму учневі [13, c. 360]. Аналогічну думку висловив Г. Ципін, пропонуючи перед безпосереднім програванням музичного тексту за фортепіано ознайомитися 3 ним шляхом уявного його прочитання, «програти його в уяві..., уявне ознайомлення з новим музичним матеріалом дає можливість повністю зосередитись на змісті музики, іiі формі і будові, гармоніях, ритмі, інтонаційних особливостях» [12, с. 51-52]. Т. Воробкевич під час читання з аркуша приділяє велику увагу розвитку вміння відчуття клавіатури наосліп, автоматичного знаходження вигідної аплікатури для будь-якої фактури і вміння дивитися на певну кількість тактів вперед у нотному тексті. «Це формується при чіткому, недовгому, але «з одного погляду» точному запам'ятовуванні невеликого уривку нотного тексту. Після запам'ятовування треба заграти цей фрагмент, не дивлячись в ноти. Існує легенда, що Ференц Ліст міг охопити таким способом вісімнадцять тактів вперед» [2, с. 169].

Крім цього, акордеоніст в своєму «арсеналі» повинен мати ряд інших знань, умінь $\mathrm{i}$ навичок, які допоможуть йому успішно долати труднощі у процесі читання музичного тексту, а саме: міцні теоретичні знання музичної грамоти, на основі яких формувати вміння зосередження під час читання, визначити форму твору, його тональний план, фактуру, жанрові i стилістичні особливості, передбачити розвиток музичної думки, фразування, мислення за розгортанням фразами, відчуття темпо-ритму твору, правильно і раціонально використовувати міховедення, добре відчувати наосліп ліву і праву клавіатуру інструмента, щоб не губити ноти, киваючи вгору-вниз головою. Отже, читання нотного матеріалу з аркуша є одним 3 чинників, що сприяє успішному розвитку виконавської майстерності акордеоніста.

Наступний чинник - це ескізне розучування музичних творів. Воно, за багатьма ознаками, схоже до читання нот з аркуша. Втім між ними є певна різниця в тому, що ескізне розучування передбачає більш детальне опрацювання творів, не доводячи їх до сценічного концертного виконання i, отже, скорочує час на їх опанування. Доцільність ескізної форми занять в класі акордеона полягає втому, що майбутній вчитель музичного мистецтва накопичує суттєву кількість інструментального навчально-педагогічного репертуару, щоб у майбутньому почувати себе «як вдома» під час проведення уроків музичного мистецтва.

Педагогами-практиками накопичений значний досвід ескізного освоєння інструментальної музики. Передусім звертається увага на репертуар, який повинен бути «максимально різноманітний за складом, стилістично різний і багатоплановий..., важливо, щоб твори, котрі розучуються в ескізній формі, подобались учневі, збуджували в ньому живий i гарячий емоційний відгук» [12, с. 52].

Практичний досвід підтверджує ці слова. Складаючи список творів для ескізного розучування, обов'язково необхідно враховувати побажання студентів, в кожного з яких є свої улюблені, омріяні твори, що з різних причин не можуть бути охоплені програмними вимогами. Тому репертуарна політика викладача має бути достатньо гнучкою $\mathrm{i}$ сміливою 3 індивідуальним підходом до кожного студента. Ця теза стосується, зокрема, складності репертуару. Практика показує, що пропонувати твори, які перевищують виконавські можливості студента, можна і потрібно.

По-перше, на вивченні складніших творів акордеоніст буде впевненішим у своїх виконавських можливостях. По-друге, це своєрідний спосіб стимулювання студента до самостійної роботи і накопичення репертуару в позааудиторний час. Викладач при цьому має можливість збільшити час на роботу в класі, яка вимагає його присутності: праця над розвитком звукоутворення, техніки, темпо-ритму, рельєфності фразування і міховедення, артикуляції, виконання орнаментики, особливостями підбору аплікатури в поліфонічних i гомофонно-гармонічних фактурах, відчуття виконавського стилю, відтворення художнього 
образу, інтерпретації твору тощо. По-трете, в процесі ескізного розучування вдосконалюються навички гри з нот. Адже не секрет, що часто вивчені напам'ять і блискуче відшліфовані твори швидко забуваються і нерідко студентові їх важко відтворити, дивлячись в ноти. Тут спрацьовує ефект заучування і автоматизму, при яких складні пасажі і технічні місця в творі просто «вилітають 3 під руки» і $з$ часом не відтворюються навіть 3 нот. Під час розучування твору ескізно від студента не вимагається вивчення його напам'ять. Тут важливо основний акцент робити на емоційному виконанні твору в художньо-виконавському стилі, де нотний текст слугує певним стимулятором, «застраховує» виконавця від помилок і технічних «зривів». Гра $з$ нот забезпечує «довше життя» навчального репертуару та й майбутня професійна діяльність вчителя набагато частіше потребує від акордеоніста вміння грати з нот, ніж сольного виконання на концертній естраді. Як показує педагогічний досвід, така самостійна робота акордеоніста буде ефективною, якщо вона систематична з боку студента і контрольована 3 боку викладача та вміло поєднана з іншими видами роботи у класі.

Важливим чинником виконавської майстерності акордеоніста є процес розкриття ідеї музичного твору й уміння його інтерпретації. Перед тим, як заглиблюватись у деталі, з'ясуємо значення терміна «інтерпретація», через яку проходить весь механізм відтворення змісту та емоційної глибини музичних творів. У мистецтвознавстві інтерпретацію розглядають як трактування музичного твору в процесі його виконання, розкриття ідейно-образного змісту музики засобами музичної виразності, технічними засобами виконавського мистецтва, наявність у виконавця власного творчого задуму. Вміння розкрити звуковий художній образ музичного твору на основі власної інтерпретації - це «той ідеал, до втілення якого виконавець постійно повинен прагнути, але який ніколи не може повністю реалізуватися: можна говорити лише про постійне наближення до нього, при цьому процес такого наближення нескінченний. Якщо ж перед виконавцем немає звукового образу, то він не зможе добре грати навіть найпростіший твір», - стверджував О. Гольденвейзер [3, с. 33].

У цьому контексті ключовим засобом постає інтонація як один з найдієвіших способів відтворення композитором навколишньої дійсності. Інтонація стала предметом дослідження багатьох вчених, музикознавців, композиторів, виконавців. Особливу цінність має робота Б. Асаф'єва «Музична форма як процес», що містить глибокий теоретичний та історичний аналіз проблем інтонації [1]. Ця праця стала теоретичним обгрунтуванням сучасного виконавства і спрямувала музикантів на пошук шляхів розкриття образно-емоційної суті виконуваних творів. Одним 3 аспектів проблеми, що розглядає автор, $є$ інтонування як виконавство. «Непроінтонована, або погано, невідповідно до своєї суті виконана музика не існує як соціальний факт, а залишається у свідомості композитора, поки він живий, або в нотному записі, поки на неї хтось не набреде» [1, с. 357].

Визначення інтонації з точки зору виконавства дає чеський вчений А. Сіхра: «Інтонація це конкретна звукова форма, що містить у собі елементи мелодичні, гармонічні, темпові, так само як і динаміку, агогіку, колорит, включаючи і всі нюанси виконання» [7, с. 14]. Такої ж думки дотримується Г. Ткаченко, стверджуючи, що «інтонаційність притаманна всім засобам музичної виразності. Виступаючи здебільшого у взаємозв'язку, комплексі, системі, вони разом утворюють інтонаційний образ» [10, с. 121].

У процесі інтерпретації твору, коли виконавець стає співавтором композитора, розкриваючи слухачу музичний образ, він проникає у цей образ через знання стилів, жанрів, виражальних властивостей ладу і його тяжінь, розв'язання інтервалів, акордів, гармонічних послідовностей, багатство образно-виражальних властивостей інтонації в комплексі виконавських засобів. I тут важливим постає вміння розшифровувати, розкривати інтонацію за виражальними властивостями. Акордеоніст повинен навчитися чути звук свого інструмента, відчути його якість i, насолоджуючись ним, відтворити інструментом звукову тканину фрази, речення, періоду, форми і загалом фактури музичного твору.

Значну привабливість у цьому контексті має праця видатного українського композитора С. Людкевича «Дві проблеми розвитку звукозображальності», де, розмежовуючи зображальність і виражальність, автор пропонує таку класифікацію [5]:

- звукозображальна музика (наслідує звучання природи);

- драматична, програмна музика (відображає стан людини та ії почуття). 
Враховуючи цю класифікацію під час роботи над інтерпретацією музичного твору, акордеоніст може успішно відтворювати звукозображальні і драматичні інтонації за допомогою тембральних регістрів правої і лівої клавіатур інструмента, які дають можливість підібрати найбільш наближений до звучання той чи інший тембр для відображення живописного i емоційного змісту музичного твору. Крім цього, як показує досвід, у студента таким способом ефективно формується вміння слухати окремий звук і звуковедення фрази, «вести звук» фізично рухом пальців, міхом і слухом до повного його завершення. А. Семешко в зв'язку цим відзначає: «Уміння слухати звук у поєднанні з відчуттям руху музики є основою не тільки в роботі над звуком, а й над всією системою виконавських навичок баяніста. Якщо студент не чує звуку до кінця, виконавський апарат стає пасивним, руки і пальці розслаблюються, кожен звук береться окремо. Фрази звучать розірвано і невиразно» [6, с. 61].

Суттєве значення в інтонаційній складовій виконавства твору має драматургія розвитку фрази, речення періоду i, зрештою, всієї форми музичної тканини. Про це говорить, зокрема, відомий факт з творчості С. Рахманінова, коли після одного концерту він був у поганому настрої і на запитання, чим незадоволений, відповів: «Точка змістилася» (маючи на увазі, що кульмінація виявилася не на місці). Такий розвиток А. Семешко називає «відчуттям горизонтального руху музики» (тобто вміння мислити і чути наперед), вміння чітко спланувати i почути так звані «горизонтальні точки» мелодії чи пасажу. Піаніст К. Ігумнов про ці кульмінації писав наступне: «Інтонаційні точки - це немовби точки тяжіння, що тягнуть за собою центральні вузли, на яких все будується. Вони дуже пов'язані з гармонічною основою. Зараз для мене в реченні, в періоді завжди $\epsilon$ центр, точка, до якої все тяжіє. Це робить музику більш злитою, пов'язує одне з іншим...» [6, с. 62]. Сказане стосується, звісно, не лише мелодичної інтонації, а й акордової. Отже, фізичне ведення звуку пальцями і його дослуховування слуховим апаратом $є$ взаємопов'язаними і взаємодоповнюючими процесами, в результаті яких формується рельєфність і довершеність інтонації, підсумовує А. Семешко.

Вирішального значення в процесі інтерпретації музичного твору виконавці завжди надавали темпу. «Вагнер, зокрема, у своїй праці «Про диригування» висловлював думку, що головне і чи не єдине завдання диригента - взяти правильний темп, бо саме це визначає життя музичного твору, як пульс - життя кожного організму, насамперед людського. Надто частий, високий пульс - смертельний, а низький (темпоритм) «заморожує» музичний твір», стверджував В. Тольба [11, с. 83]. Подібне говорив О. Гольденвейзер: «Кваплива гра і швидка piзні речі. Можна грати в темпі presto й не квапити, а можна квапити й у темпі adagio» [3, c. 29]. 3 теорії музики нам відомо, що ритм і темп - нероздільні поняття, тому в музичній лексиці найчастіше поняття темпу і ритму об'єднують в темпоритм.

У нотній літературі зустрічаються різні позначення темпу. Традиційне - через словесне пояснення емоційного та рухливого виконавського відтворення характеру музики i через підрахунок долей такту із застосуванням метронома. Однак такі позначення дуже умовні, бо під час інтерпретації виконавець має враховувати різні аспекти: розмір твору, його фактуру, стильові особливості, традиції і новаторство, сучасні підходи до трактування i, зрештою, особисті відчуття темпо-ритму. Один і той же твір один інструменталіст виконує у вільному стилі з темповими відхиленнями, широкою агогікою, а інший дотримується педантичної метричної точності без будь-яких відхилення від метронома. Разом з тим у будь-якому разі при виконанні твору все таки, на нашу думку, виконавцеві варто вибирати такий темп, щоб не порушувалася форма і композиторський задум твору.

Отже, ми перелічили основні чинники, вимоги до виконавської майстерності акордеоніста - майбутнього вчителя музичного мистецтва, а саме: вміння виконувати твори різного стилю і форми в процесі читання нот з листа; володіння навичками самостійної роботи над музичним твором під час ескізного вивчення творів 3 метою поповнення репертуару навчального репертуару для слухання музики; вміння розкривати музичний образ музичного твору в процесі його інтерпретації.

За наявності цих чинників виконавська майстерність інструменталіста (в даному контексті акордеоніста), звісно, піднімає авторитет вчителя музичного мистецтва. Володіючи нею на високому рівні, він у процесі фахової діяльності вирішує ряд важливих педагогічних і культурно-мистецьких завдань. 


\section{ЛITЕРАТУРА}

1. Асафьев Б. Музыкальная форма как процесс. Л.: Музыка, 1971. 366 с.

2. Воробкевич Т. П. Методика викладання гри на фортепіано: підручник. Львів: ЛДМА, 2001. 224 с.

3. Гольденвейзер О. Роздуми про музику, виконавське мистецтво та фортепіанну педагогіку. Музична педагогіка та виконавство: збірник статей. Вип. 3 / упоряд. П. Ф. Серотюк; за заг. ред. проф. А. А. Семешко. Тернопіль: Навчальна книга - Богдан, 2009. С. 29-36.

4. Гофман Й. Фортепианная игра. Ответы на вопросы о фортепианной игре. М.: Музгиз, 1961. 188 с.

5. Людкевич С. Дві проблеми розвитку звукозображальності. Дослідження, статті, рецензії, виступи. К.: Музична Україна, 1976. С. 19-106.

6. Семешко А. Виконавська майстерність баяніста. Методичні основи: навч. посібник. 2-е вид. Тернопіль: Навчальна книга - Богдан, 2009. 144 с.

7. Сихра А. Музыковедение и новые методы научного анализа. Интонация и музыкальный образ. М.: Музыка, 1965. С. 9-34.

8. Стельмащук 3. М. Інструментальна підготовка як складова формування педагогічної культури майбутнього вчителя музичного мистецтва в процесі кредитно-трансферної системи навчання. Формування професійної культури вчителя в контексті інтеграиї̈ Украӥни в європейський освітній простір. Матеріали регіон. наук.-практ. семінару / за ред. проф. Г. В. Терещука. Тернопіль: Вид-во ТНПУ ім. В. Гнатюка, 2007. С. 75-77.

9. Теплов Б. М. Проблемы индивидуальных различий. Избранные работы. М.: Изд-во АПН РСФСР, $1961.536 \mathrm{c}$.

10. Ткаченко Г. Диригентська інтерпретація оперного спектаклю. Питання диригентськоӥ майстерності / упоряд. М. Канерштейн. К.: Музична Україна, 1980. С. 120-143.

11. Тольба В. Проблеми виконавства. Питання диригентської майстерності / упоряд. М. Канерштейн. К.: Музична Україна, 1980. С. 78-105.

12. Цыпин Г. Развитие учащегося фортепианного класса: формы и методы. Вопросы музыкальной педагогики. Вып. 1. М.: Музыка, 1979. С. 51-52.

13. Шуман Р. Избранные статьи о музыке. М.: Музгиз, 1956. 400 с.

\section{REFERENCES}

1. Asafiev B. Muzykalnaia forma kak prozess [Musical form as a process.]. L.: Muzyka, 1971. $366 \mathrm{~s}$.

2. Vorobkevych T. P. Metodyka vykladannia hry na fortepiano [Methodollogy of piano playing]. pidruchnyk. Lviv: LDMA, 2001. $224 \mathrm{~s}$.

3. Holdenveyzer O. Rozdumy pro muzyku, vykonavske mystetstvo ta fortepiannu pedahohiku [Reflections on music, performing arts and piano pedagogy.]. Muzychna pedahohika ta vykonavstvo: zbirnyk statei.Vyp. 3 / uporyad. P. F. Serotyuk; za zah. red prof. A. A. Semeshko. Ternopil: Navchalna knyha - Bohdan, 2009. S. 29-36.

4. Hofman I. Fortepiannaya ihra. Otvety na voprosy o fortepiannoy ihre [Piano playing. Answers to questions about piano playing]. M.: Muzhiz, 1961. $188 \mathrm{~s}$.

5. Lyudkevych S. Dvi problemy rozvytku zvukozobrazhalnosti [Two problems of sound imaging development]. Doslidzhennya, statti, rezenzii, vystupy. K.: Muzychna Ukraina, 1976. S. 19-106.

6. Semeshko A. Vykonavska maysternist bayanista. Metodychni osnovy: [Performing skills of the accordionist. Methodical bases:] navch. Posibnyk. Ternopil: Navchalna knyha - Bohdan, 2009. 144 s.

7. Sikhra A. Muzykovedenie I novye metody nauchnoho analiza [Musicology and new methods of scientific analysis]. Intonaziia i muzykalnyi obraz. M.: Muzyka, 1965. S. 9-4.

8. Stelmashchuk Z. M. Instrumentalna pidhotovka yak skladova formuvannia pedahohichnoi kultury maybutnoho vchytelia muzychnoho mystetstva $\mathrm{v}$ prozesi kredytno-transvernoi systemy navchannia [Instrumental training as a component of the formation of pedagogical culture of the future teacher of music in the process of credit-transfer system of education. Formation of professional culture of a teacher in the context of Ukraine's integration into the European educational space]. Formuvannia profesiynoi kultury vchytelia $v$ konteksti intehrazii Ukrainy v Yevropeiskyi osvitnii prostir. Materialy rehion. nauk.-prakt. seminaru / za red. prof. H. V. Tereshchuka. Ternopil: Vyd-vo TNPU im. V. Hnatiuka, 2007. S. 75-77.

9. Teplov B. M. Problemy individualnykh razlichii [Problems of individual differences]. Izbrannye raboty. M.: Izd-vo APN RSFSR, 1961. $536 \mathrm{~s}$.

10. Tkachenko H. Dyryhenska interpretaziia opernoho spektakliu [Conductor's interpretation of an opera performance]. Pytannia dyryhenskoi maysternosti. K.: Muzychna Ukraina, 1989. S. 120-143.

11. Tolba V. Problemy vykonavstva [Problems of performance]. Pytannia dyryhenskoi maysternosti. K.: Muzychna Ukraina, 1980. S. 78-10.

12. Zypin H. Razvitie uchashchehosya fortepiannoho klassa: formy i metody [Development of the student of a piano class: forms and methods]. Vopros ymuzykalnoi pedahohiky. Vyp. 1. M.: Muzyka, 1979. S. 51-52.

13. Shuman R. Zhiznennye pravila dlia muzykantov [Life rules for musicians]. Izbrannye stati o muzyke. M.: Muzhiz, 1956. $400 \mathrm{~s}$. 